\title{
Predicaments and Strategies of Moral Education and Personnel Cultivation for Private Universities
}

\author{
Zhijun Yang \\ Engineering and Technical College \\ Chengdu University of Technology \\ Leshan, Sichuan, China 614000
}

\begin{abstract}
Moral education and personnel cultivation is the mission of education, especially of private higher education, though many problems lay before us. Only through an analysis of the predicaments to find the corresponding strategies, can we really complete the mission of moral education and personnel cultivation for private universities so as to realize the scientific development of private higher education.
\end{abstract}

Keywords—private universities; moral education and personnel cultivation; predicaments; strategies

\section{INTRODUCTION}

Chinese leader Xi Jinping points out, "In order to run universities of socialism with Chinese Characteristics, it is necessary to insist moral education and personnel cultivation and integrate the cultivation and practice of socialist core values in the whole process of imparting knowledge and educating people". The instruction of general secretary $\mathrm{Xi}$ Jinping emphasizes that universities shall insist moral education and personnel cultivation, which has very important guiding significance on higher education. Report of the 18th National Congress of the Communist Party of China points out to "take moral education and personnel cultivation as basic mission and cultivate socialistic builders and successors with all-round development of morality, intelligence, physique and aesthetic." The Report first sets moral education and personnel cultivation as basic mission of education and indicates directions for education from the perspective of strategy. Moral education and personnel cultivation is the mission of education, especially of private higher education, though many problems lay before us. Only through an analysis of the predicaments to find the corresponding strategies, can we really complete the mission of moral education and personnel cultivation for private universities so as to realize the scientific development of private higher education.

\section{PRACTICAL SIGNIFICANCE ON REGARDING MORAL}

EduCATION AND PERSONNEl CULTIVATION AS BASIC Mission OF PRIVATE HighER EDUCATION

The Report of the 18th National Congress of the Communist Party of China puts "making efforts to realize education that makes people satisfied" in the first place of social construction that focuses on guaranteeing and improving people's livelihood. As the cradle of talents cultivation, higher

CLC: G641 Document code: A education is the important position for moral education and personnel cultivation. Private higher education has become an important part of regular higher education of our country. Whether private universities set moral education and personnel cultivation as basic mission of education concerns private universities can cultivate qualified socialist builders and successors or not. It has very important guiding significance on education of private universities.

\section{A. The Primary Task of Private Universities}

The report sets moral education and personnel cultivation as basic mission of education, which is the deepening of educational idea that "education of people as the center and moral education as the priority" put forward in the 17th National Congress of the Communist Party of China, as well as the latest summary of essential attributes and basic mission of education. It emphasizes that schools shall not only impart knowledge and train ability, but also practically integrate cultivation and practice of socialist core value in the whole process of imparting knowledge and educating people, as well as propagating the doctrine and resolving doubts, and turn it into conscious behaviors of students. The educational work is to educator people. In school education, teaching by example is more important than teaching by word of mouth. The responsibility of imparting knowledge and educating people is heavy; to educate people, moral education shall be put in the first place; moral education and personnel education is the basic mission of higher education as well as the primary task of private universities.

\section{B. Basic Requirement of Society for Private Universities}

Institutions of higher learning are important position of civic moral construction and play the roles of education, demonstration and radiation in moral construction of society. Under the background that our country gives priority to developing education and prospering the nation through science and education and strengthening the country through talents, Chinese higher education, especially private higher education has achieved considerable development. The differences between private universities and public universities only exist in financial resources. Requirements of the country and society on private colleges are the same as public universities. The society pays increasingly high attention to private higher education and the expectation is higher and higher. It attaches more importance to whether private 
universities set moral education and personnel cultivation as basic mission of education, and whether they put energy in teaching and scientific research and discipline construction as well as social responsibility in building harmonious campus with moral self-discipline.

\section{Promote Sound Development of Private Universities}

The fundamental guarantee of sound development of private universities is to set up educational idea of moral education and personnel cultivation. Private universities shall put moral education and personnel cultivation in the first place of school education. Without educational idea of moral education and personnel cultivation, private universities will lose the premise of survival and basis of development. Social approval degree of private universities intensively reflects whether this school has educational idea and theory on school management of moral education and personnel cultivation. Only having this idea can private universities acquire sustainable and sound development; form their own brands and win respect and recognition of students, parents and society.

\section{PREDICAMENTS OF MORAL EDUCATION AND PERSONNEL CULTIVATION FOR PRIVATE UNIVERSITIES}

Predicaments of moral education and personnel cultivation for private universities come from social environment and private universities. Moral education and personnel cultivation is basic mission of education, especially of private higher education. It should be the problem that "is no problem at all". However, because of special educational body, financial resources, management mode and quality of students, the problem that "is no problem at all" is imperfect on educational and teaching practice of private universities.

\section{A. Lack of Social Responsibility}

The basic theory on school management and guiding thought of universities is responsible for the society as well as the mission that must be remembered well by private universities. However, some private universities have impure motives to run school, nonstandard school running behavior and deviate direction of school running of socialism. Quite a few private universities neglect basic laws of education, run school with marketable operation, anxious to recover school running cost, blindly expand the scale of school and pursue economic benefit of school running. Fading social responsibility and public welfare education and losing standard of education behavior will lead to low quality of education and influence stability and development of private universities and society. Some private universities seek quick success and instant benefits in the process of school running, adopt market mechanism to allocate educational resources, adopt enterprise management model to operate and turn school running into enterprise running. In order to reduce school running cost to the greatest extent, they even adopt measures such as shrink the courses in disguised form, lower requirement of teaching, loose teaching management and reduce standards of talents cultivation to make more benefits, which damage lawful rights and interests of education consumers. These undesirable phenomena show on that some private universities do not put more energy in fulfilling their social responsibility, which endanger the reputation of private higher education and influence the image of private universities, destroy expectation of the public on private universities. It will inevitably lead to slow development of private higher education and become the biggest obstacle for sound development of private universities.

\section{B. Pay no Attention to Connotative Development}

Extensive growth is the main development mode of private universities, which is realized mainly through expansion in scale and growth in number of private universities. Private universities pay no attention to connotative development without distinctive school running quality and characteristics. They mainly face the market to allocate resources with selffinancing, assume sole responsibility for their profits and losses. The main income source is tuition fee of students. Many private universities develop with liabilities and excessive economic pressure. They pay more attention to efficiency and economic benefit and focus on increasing enrollment at all costs. Leaders of some private universities think the development is expanding of quantity and scale; lack of quality consciousness, blindly pursue quantity and pay no attention to quality problem for a long time. They attach importance to enrollment and employment, the number of students at school and employment rate of graduates; pay attention to passing rate of courses and employment of students instead of teaching process and quality; eager to expand the scale of school, neglect to put the improvement of teaching quality in a very important place. The internal management system of private universities is not sound. Problems existing in teaching faculty, experimental facilities, books materials, and infrastructure, teaching and scientific research are serious. Great gap exists between school size and conditions, which lead to low quality of teaching.

\section{Think Little of Ideological and Political Education}

Ideological and political education of universities is of vital importance, but it is difficult for private universities to implement it. Although Publicity Department of the Communist Party of China, Ministry of Education have clear requirements on Party building and ideological and political education in organization structuring, team construction, curriculum provision and guarantee of conditions, influenced by degree of attention paid by the operator to ideological and political education and restricted by factors such as school running cost, private universities will strictly control organization structuring, size of personnel force and expenditure of ideological and political education. Most private universities put inadequate manpower and financial resources in ideological and political education, which influence whole work and effect of ideological and political education in universities. Different from public universities, private universities do not have complete ideological and political education system and have the problems such as organizations of ideological and political education are unsound; the work team of ideological and political education is weak; the number of full time and part-time teachers of ideological and political education is seriously insufficient; expenditure and condition guarantee are inadequate. Ideological and political education lacks necessary system guarantee and separates from educational management and 
professional education. The ideological and political theory course has no relationship with daily ideological and political education, so that the management objectives do not conform to the purpose of personnel cultivation. It is very difficult to guarantee effective implementation of ideological and political education work.

\section{Schools Lack Cohesive Force}

Private universities show obvious characteristics of leadership of the board of directors, operation of stockholding system and family-run management. Private universities and employees have "employment relationship" in reality. Teachers in public universities belong to staffing of government affiliated institutions, with stable job and good treatment, while teachers in private universities cannot enjoy these treatments. Most investors of private universities are entrepreneurs. The management layer often follows what the investors say. If they have a good relationship with the boss, they will get a good job; they often think the growth of teachers is the personal matter of teachers. Private universities give less consideration to future development of teachers and do not offer enough platform and development space for teachers. Self-actualization need of teachers cannot be met; the welfare benefits for teaching and administrative staff are insufficient. Living conditions of staff cannot be improved. When teachers meet confusions or difficulties in work and life, there is no place for them to seek help. Teachers are often regarded as employees, so they seriously lack senses of belonging and achievement; teaching and administrative staff obey the arrangement of "boss" and just regard their job as a means to make a living, lacking sense of ownership and the consciousness to actively educate people. The teaching body is unstable and has big mobility. Quite a few teachers cannot work contentedly. Schools lack of cohesive force.

\section{E. The Educatee Belongs to A Special Group}

Students in private universities belong to a special group in college students group and show distinctive characteristics. The status and social approval degree of private universities in the whole regular higher education are relatively low, so graduates are discriminated in employment. Substantial number of students has sense of inferiority and resistance. The tuition fee of private universities is high. Students have to pay full tuition. The relationship of educational consumption exists between schools and students. Compared with students in public universities, they have unfair educational consumption in reality; great differences exist between high tuition fees and quality of teaching. Estrangement even conflicts appear between students and schools. Private universities enroll students in the last batch every year. With large-scale enrollment increase of public universities, it leads to the situation that the source of students is few for private universities to select. Students enrolled by them have low marks in college entrance examination, so the quality of them is inevitably low. Objectively speaking, the comprehensive quality of some students is lower than that of students in public universities. Besides, on daily education and management of students in private universities, full time leaders for management of students are inadequate. The phenomenon that administrative staff replaces "education" with "management" is widespread. In order to complete the basic mission of moral education and personnel cultivation, it is more difficult for private universities than public universities.

\section{COUNTERMEASURES OF MORAL EDUCATION AND PERSONNEL CULTIVATION FOR PRIVATE UNIVERSITIES}

Report of the 18th National Congress of the Communist Party of China emphasizes taking moral education and personnel cultivation as basic mission of education, which has strong realistic pertinence. It focuses on the lack of educational nature of schools and teachers existing at present. Problems existing in moral education and personnel cultivation of private universities influence sound development and social stability of private higher education. We should pay high attention to and timely solve them. In terms of weak link of private universities in moral education and personnel cultivation, it is necessary to take measures from the following five aspects.

\section{A. Moral Education and Personnel Cultivation, Centering on Educating People}

The leadership system of private universities is headmaster-in-charge system under the leadership of board of directors. It is greatly different from public universities in aspects such as leadership system, school-running mechanism, management style and financial resources, but the mission to deliver qualified talents for the country and society is the same. Educational idea determines whether the school running direction is correct or not. Moral education and personnel cultivation is the starting point and end result of various works of schools. Moral education and personnel cultivation should become educational idea of private higher education. The basic mission of education is moral education and personnel cultivation, which further points out direction for private universities. Private universities shall focus on "offering what kind of education and how to educate people", fully implement educational policy of the Party, insist school running direction of socialism and pay attention to solving problems of "how to implement moral education and personnel cultivation". In addition, private universities shall establish sound Communist and Youth League organizations, enrich staff of ideological and political work and strengthen ideological and political education. Insist cultivation-orientation, put talents cultivation in the central position of school work and put personnel cultivation in the first place of education and teaching work. Let cultivation of ideology and morality, scientific spirit and practical ability run through the whole process of talent cultivation, cultivate high quality talents with potential of development. In the process of education and teaching, regard students as the principal part, establish the point of view that all works of school is good for students' progress, development and growth, and make efforts to create conditions for health growth and development of college students. Profoundly grasp theoretical significance and practical significance of moral education and personnel cultivation, pay attention to training scientific and cultural quality of college students and greatly improve ideological and moral quality of them. Take moral education and personnel cultivation as primary task of educational work in schools, turn educational 
idea of moral education and personnel cultivation into guiding thought of school work and realize profound change of moral education and personnel cultivation from ideological understanding to work idea. Center on improving the quality of personnel cultivation, vigorously create brand of personnel cultivation and enhance popularity and influence of private universities, and fundamentally improve intellectual impetus and executive force of moral education and personnel cultivation of private universities.

\section{B. Fulfill Social Responsibility, not for the Purpose of Making Profits}

Although private universities are institutions of higher learning that use non-state fiscal expenditure of education and serve the whole society, in essence, they work on education activity. They are not enterprises but educational institutions and non-profit organizations. Private universities shall follow objective law of teaching of higher education, advocate ideas of modern university and fulfill historical mission responsible for the country and society in real earnest. Our country pays high attention to higher education and places high hopes on higher education in the construction of strengthening the country through talents. The guiding significance of higher education in development of the whole society is particularly prominent, so higher education shoulders weighty social responsibility. Responsible for the society is decided by social function, essential attributes and responsibility of institutions of higher learning and it is the source of survival and competition of private universities. At present, private universities fulfill social responsibilities, namely insist the principle of public welfare of education, enrich and improve school running conditions, not for the purpose of making profits, firmly reject the tendency of seeking quick success and instant benefits, put national interest, social interest and interests of the people in the first place; actively serve local economic and social development, cultivate more professional talents for the society and run universities that make people and the society satisfied. If aiming at making profits, it is impossible for private universities to do it well. Organizers and operators of private universities must remember well and fulfill social responsibilities in real earnest, serve our country, society and people, build fine reputation and popularity and strengthen soft power of development of private universities, so as to improve overall competitiveness of private universities.

\section{Improve Quality of Teaching and Pay Attention to Connotative Development}

Extensive development lays emphasis on expanding of scale of schools. Intensive development is connotative development focusing on improving quality. The teaching quality of private universities receives special attention of the society. It is the problem that urgently needs the solution from private universities. Quality is lifeline of school development. In order to realize connotative development of private universities, it is necessary to pursue the improvement of quality of school running and firmly establish the central position of quality in vigorously developing schools. Private universities shall deepen education and teaching reforms, improve internal management system, standardize school running behaviors, and strengthen connotation construction, settle to change from scale expansion to quality improvement and make efforts to improve quality of school running. They shall continuously reform personnel training mode on the basis of their own conditions and optimize personnel cultivating program. Stabilize scale, optimize structure, strengthen characteristics and pay attention to innovation and make every endeavor to let students learn knowledge and skills truly. Firmly establish people oriented idea, realize "student-centered education" and practically deal with relations between efficiency in school management and quality of school running. In order to improve core competitiveness, private universities shall pay attention to expanding of scale as well as improvement of quality, so that they can realize connotative development.

\section{Strengthen Construction of Teaching Staff and Stabilize Teaching Body}

The work of schools is to educate people. The quality of personnel cultivation is decided by teachers, who are hard core of private universities as well as footstone of school development. The connotative development of private universities cannot do without high quality teaching staffs that cherish posts and devote wholeheartedly to work and cultivate personnel with enthusiasm. Teachers in universities shall be learned and teach by personal example as well as verbal instruction through their profound knowledge to touch large numbers of students and become examples for students to imitate and learn. The mentality of teachers dominates their behaviors. Behaviors of teachers have close relationship with development of schools and growth of students. It is necessary to care about lives of teachers, improve living environment, guarantee wages and social benefits of teachers, and solve livelihood issues of them, let achievements of reform and development of schools benefit all teachers. Create good environment for teachers to whole-heartedly devote to teaching, scientific research, management, ideological and political education, keep teachers by cause, management, treatment, emotion and environment, make teachers full of passion and hope and regard education as noble cause. Intensify cultivation and education of teaching staff, provide platform of career development and space of growth for teaching staff; propel democratic management and democratic decision-making of schools, let teachers participate in various works of the school with sense of ownership; amplify appraisal management system to stimulate teachers to work hard wholeheartedly.

\section{E. Create Atmosphere of Campus Culture, Correct Style of Study and Improve Quality}

Education characteristics of schools lie on individuality of cultural connotation. Private universities have short history of school running in general. Without certain cultural deposits, it is difficult to form unique atmosphere of campus culture. The connotation of university culture is of vital importance. Excellent campus culture plays a guiding role in construction of study style. Atmosphere of campus culture with rich connotation and good school spirit and study style have positive influence on college students and can gather positive energy. Under subtle influence, students can feel an education power and arouse enthusiasm for learning and innovation. 
Good study style is the basis to establish stable teaching order and good learning atmosphere. It can promote self-education, self-management and self-discipline of students and effectively improve ideological and moral quality as well as scientific and cultural quality of students. Schools shall not only have tangible places such as classroom, library, laboratory and playground, but also have intangible cultural environment: school motto, school song, school history, culture wall, academic and scientific research atmosphere and democratic school-running mechanism. Schools shall make use of important ceremonies and festivals to carry out thematic education activities with distinctive characteristics such as patriotism, national tradition and manners etiquette, create atmosphere of campus culture that cultivates and practices socialist core values and let students cultivate their taste in appeal of advanced culture in campus. Rich cultural activities in campus can improve sense of identity and cohesive force of all teachers and students, promote school spirit and study style and improve comprehensive quality of students.

Moral education and personnel cultivation is the requirement details for private universities to run school and train talents. In order to realize connotative development, private universities must firmly grasp the basic mission of moral education and personnel cultivation, pay attention to solving the significant problems of "cultivating what kind of people and how to cultivate people". Only by putting the basic mission into practice and implementing the idea of moral education and personnel cultivation in various works of private universities can we prevent education of private universities from deviating direction from the source and cultivate qualified builders and successors of socialist cause with Chinese characteristics.

\section{REFERENCES}

[1] Li Zhao. Responsible for the Society: Missions That Must Be Remembered by Private Universities [M], Heilongjiang Researches on Higher Education, 2009, 03

[2] Li Haifeng. Problems Existing in Ideological and Political Education of Private Universities and Countermeasure Discussion [J], Theoretic Observation, 2011, 02

[3] Gong Ke. Moral Education and Personnel Cultivation, Quality-oriented Education and Connotative Development [J], Chinese Higher Education, 2013, 02

[4] Fang Xiaozhen. Theoretical Direction and Practice Approach of "Moral Education and Personnel Cultivation" in Universities [J], Journal of Ideological \& Theoretical Education 